\title{
The Development of E-Learning Tools Used for Teaching English for Law Enforcement
}

\author{
Judit Borszéki \\ ORCID: 0000-0002-9938-6980 \\ University of Public Service, Hungary
}

\begin{abstract}
International (operational and training) activities carried out by law enforcement officers have been accompanied by the growing realisation of the fact that it is essential for those involved in them to communicate efficiently, in one common language, basically English. However, even in the last few years, the gaps between the foreign language skills of the law enforcement professionals and the need for further foreign (mainly English) language training courses have been underlined several times in international professional and legal documents. Also, the fact that specific-purpose English language courses continue to be important content elements of the curricula both of national law enforcement training institutions and the two largest $E U$ agencies involved in the training of police officers, as well as border and coast guards (CEPOL and Frontex), proves that this problem still exists.

Using the qualitative research and providing an overview and evaluation of the most significant e-learning trends and tools used in teaching English for Law Enforcement by CEPOL and Frontex in the last decade, the paper discusses the progress made in this field in terms of both quality and methodology. It presents technical limitations of certain e-learning tools and points to the course developers' ensuing realisation that the virtual or real presence of the teacher is indispensable in language courses.
\end{abstract}

DOI: 10.5604/01.3001.0015.2908

http://dx.doi.org/10.5604/01.3001.0015.2908

Keywords: law enforcement cooperation, language course, Learning Management System, mobile devices

\section{Introduction}

Given today's complex security threats, international law enforcement cooperation within the EU as well as with neighbouring third countries has become increasingly important in the last few decades. One of the latest documents confirming that fact is the European Agenda on Internal Security', which highlights the need for further synergies and closer cooperation in all three priority areas (terrorism, organised crime and cybercrime), all of which have a strong cross-border dimension. ${ }^{2}$ International (operational and training) activities carried out by law enforcement officers have been accompanied by the growing realisation of the fact that those involved in them must communicate efficiently in one common language, basically English ${ }^{3}$. Thus, it is

${ }^{1}$ European Commission: European Agenda on Security COM(2015) 185 final. Electronic source: https://ec.europa.eu/home-affairs/sites/homeaffairs/files/e-library/documents/basicdocuments/docs/eu_agenda_on_security_en.pdf accessed: 20.11.2020.

2 The crucial importance of international cooperation in detecting and intercepting serious cross-border crime is frequently emphasised. Cf.: Ürmösné Simon, G: The traits and the thrill of serial killers. Internal Security, 2015, Vol 7, Issue 2.

3 See also: Kovács G, The Hungarian law enforcement education system at the National University of Public Service: the best practice of Hungary. European Police Science And Research Bulletin, 2017, Vol. 3, pp. 93-99; Kovács G, The practice-oriented training and education system at the National University of Public Service: The common public service practice. Belgrade: Academy of Criminalistic and Police Studies, 2015, pp. 49-56. 
necessary to develop foreign language teaching for law enforcement staff in the EU. This is often related to the concepts of training standardisation. However, even in the last few years, the gaps in the law enforcement professionals' foreign language skills and the need for further foreign (mainly English) language training courses have been underlined several times in international professional and legal documents.

In 2011 and 2012, at the request of the European Commission, CEPOL ${ }^{4}$ mapped national and international law enforcement training courses conducted in the member states and summarised the results of the survey. ${ }^{5}$ Following this report, under the strategic guidelines for developing internal security, the communication from the Commission ${ }^{6}$ was published in 2013. It outlined the factors that make it necessary to establish the Law Enforcement Training Scheme (LETS), the main areas of its operation and strategy, ways of assuring quality standards and its organisational framework. Almost all of the four training strands identified in this document are related to international cooperation, which requires the knowledge of English. In Section 2.3 of the same document (entitled Training gaps), it is mentioned that language skills, including English, which is increasingly used in cross-border cooperation, are a crucial competence for all law enforcement officials involved in cross-border cooperation. However, there are still too few officials available with language skills of a sufficiently high standard in many Member States.' The existence of the above-mentioned problem is proved by the fact that specific-purpose English language courses continue to be important content elements of the curricula both of national law enforcement training institutions and of the two largest EU agencies involved in the training of police officers as well as border and coast guards (CEPOL and Frontex ). (See also Borszéki ${ }^{8}$ ) (This major problem concerns national law enforcement organisations, too. The results of basic competency research conducted in 2017 prove that language skills are also needed by those entering public service as members of law enforcement organisations. The need for language proficiency has been highlighted by almost all interviewees taking part in a research project conducted within the Hungarian National Tax and Customs Administration, most of whom were required to have English language skills. ${ }^{9}$ ) (See also: Borszéki ${ }^{10}$.)

${ }^{4}$ Former European Police College, since 2016 the European Union Agency for Law Enforcement Training.

${ }^{5}$ CEPOL: European Training Scheme: Mapping of Law Enforcement Training in the European Union - Management Summary. Electronic source: https://enet.cepol.europa.eu/ fileadmin/documents/LETS/LETS_Management_Summary.pdf, accessed: 20.11.2020.

${ }^{6}$ European Commission: Communication from the Commission to the European Parliament, the Council, the European Economic and Social Committee and the Committee of the Regions: Establishing a European Law Enforcement Training Scheme (COM/2013/0172 final) Electronic source: https://eur-lex.europa.eu/LexUriServ/LexUriServ.do?uri=COM:2013:0172:FIN:EN:PDF, accessed: 20.11.2020.

7 European Border and Coast Guard Agency.

${ }^{8}$ Borszéki J, Training border policing experts in English for specific purposes (ESP): Uniform trends in EU member states., [in:] Kaljula D (Ed.), Sisekaitseakadeemia Teadusartiklid: Valikkogu. Tallinn, 2016, pp. 31-65.

9 Magasvári A, What is a good entrantinto the labour market?The expectations of the National Tax and Customs Administration, Tudásmenedzsment, 2018, Issue 2, pp. 123-130. Electronic source: http://btk.pte.hu/sites/btk.pte.hu/files/files/xix.evf_.2.szam_.pdf accessed:26.11.2020.

${ }^{10}$ Borszéki J, A Rendőrség határrendészeti feladatokat ellátó állományának idegen nyelvi ismeretei és érdeklődése a nemzetközi határrendészeti tevékenységek iránt, [in:] Szelei I, Berki G (Eds), A hadtudomány és a 21. század, Tanulmánykötet. Budapest, 2015, pp. 163-196. 
Language learning is a complex and time-consuming process and, as it concerns a large number of (future and already operational) law enforcement staff, it is self-evident that those involved in developing training courses of English for Law Enforcement have sought new and more efficient ways and technologies suitable to deliver such content. (See also: Pielmus ${ }^{11}$.)

To my knowledge, the most significant e-learning ${ }^{12}$ trends and tools used by CEPOL and Frontex in the last decade in teaching English for Law Enforcement have not been investigated. Therefore, by using qualitative research and giving an overview and empirical evaluation, this paper aims to prove that they represent progress in terms of both quality and methodology.

\section{From portable data carriers to learning management systems and mobile devices}

\section{The beginnings: CDs and DVDs}

The first (and up to this day last) English book for law enforcement officers entitled English for Law Enforcement was developed for the international market by a large publisher, Macmillan English, in 2009. Similarly to the general English textbooks of the time, it was accompanied by CDs, instead of cassettes, for audio listening content and also by a CD-ROM to provide additional interactive practise of grammar, vocabulary and situational language.

As a response to the abovementioned problem concerning the law enforcement staff lacking operational English skills (i.e. the need to provide training to a large number of students in a short period), the EU agencies responsible for training police officers and border guards ${ }^{13}$ launched their own projects for the development of e-learning English tools to respond to the urgent need. (A phenomenon also typical in e.g.. higher education in general.) It was probably the relative ease of ICT materials development and their distribution - made possible by the widely used electronic systems and devices as well as the technological development usually referred to as Web 2.0 - that facilitated the process.

As a member of the international team involved in the design and development of an ICT Learning Tool for Police English in 2009 and 2010, I saw the beginnings of e-learning implemented by CEPOL, as the communication among the team

11 Pielmus C.G, Innovation in Teaching English for Law Enforcement: A Technology-Integrated Approach, Society. Integration. Education. Proceedings of the International Scientific Conference, 2018, Vol. 3, pp. 566-579. Electronic source: http://journals.rta.Iv/index.php/SIE/ article/view/3074/3102, accessed: 30.10.2020.

12 For the purposes of this paper, the term 'e-learning' will be used in a broad sense, meaning course design and learning using any kind of ICT device, including computers, smart devices, the Internet, etc.

${ }^{13}$ For the purposes of this paper, the term 'border guard' will be used in accordance with the Schengen Borders Code, meaning 'Any public official assigned, in accordance with national law, to a border crossing point or along the border or the immediate vicinity of that border who carries out ... border control tasks'. 
members was conducted via the Moodle-based LMS that had recently been introduced. The learning material covered three language proficiency levels (A2, B1 and B2) and 13 topics ranging from everyday duties to the theoretical knowledge necessary for fulfilling policing tasks. The syllabus and the sets of exercises for the development of students' terminology, reading and listening skills were created. Unfortunately, the project was not finished. Certain parts of the learning content are still available in the CEPOL LMS.

The need for developing ESP (English for Specific Purposes) competencies of border guards resulted in the launch of the Training in English Communication for Border Guards project of the Frontex Training Unit in 2010. It aimed to build common language capabilities among EU Member States (MS) and Schengen Associated Countries (SAC) border guards at airports so that they will be able to communicate in English in their daily tasks and during joint operations coordinated by Frontex. ${ }^{14}$ By creating the first English language training tool of the project, entitled Basic English for Border Guards at Airports, (EBGA) Frontex wanted to offer an opportunity to border guard staff to develop their skills by self-access learning. ${ }^{15}$ The interactive $C D$ was meant for those with a basic knowledge of English (A2/B1 level according to the $\left(\mathrm{CFR}^{16}\right)$. The project involved experts from $24 \mathrm{EU}$ and Schengen member states and 6 third countries. The CD was made accessible in the EU and the Schengen area, exclusively to the law enforcement staff.

The material was divided into four units: Border Check, Giving Information, Personal Presentation and Security Control, based on the main domains of language activity border guards conduct at airports. Each unit had the same five sections: Vocabulary, Phrases, Listening texts, Videos and Exercises.

The Users' Guide on the CD suggested that learners first choose a unit and study the related vocabulary (they were able to read the translation of the phrases in their mother tongue and listen to the pronunciation of the English phrase) and memorise it. Then, they were advised to listen to/watch the audio/video sequences of the dialogues, first trying to understand as much as possible, and then to proceed to read the scripts or subtitles and look up new words in the glossary, if necessary. After memorising the dialogues, the learners were able to test their knowledge with the 'open dialogue' technique, i.e. stopping the recording at a certain point and playing the border guard's role and then comparing their production with the correct solution in the original recording. Finally, they were given the opportunity to apply their knowledge in new contexts using various exercises (crosswords, gapfilling, matching, mixed sentences, multiple-choice exercises, etc.) with qualitative and quantitative feedback on their performance in revision exercises and the final Assessment section. Listening to the dialogues and doing the exercises had to be regularly repeated to improve learners' English language skills. The electronic tool aimed to develop English language skills necessary for the interactive oral activities

${ }^{14}$ Frontex: Mid-Level English for Border Guards at Airports, Instruction Booklet, 2013 (electronic teaching material on DVD).

15 Frontex: Basic English for Border Guards at Airports, Introduction. 2011 (electronic teaching material on $\mathrm{CD}$ ).

${ }^{16}$ Council of Europe: Common European Framework of Reference for Languages: Learning, Teaching, Assessment. Electronic source: https://rm.coe.int/16802fc 1 bf, accessed 10.10.2020. 
most frequently encountered at work by the given target group of border guards. The discourse featured in the material represented real-life conversations. The dialogues were constructed based on many years' empirical experience gained by border guards in their work on a day-to-day basis and were modelled according to the typical domains of language use, focusing on a limited range of border policing vocabulary, i.e. phrases related to activities at airports. ${ }^{17}$ After the tool was implemented at national levels in 2010-2012, Frontex conducted research using qualitative and quantitative analysis of feedback questionnaires received from $21 \mathrm{MS} / \mathrm{SAC}$. The results showed an increase in border guards' language skills and competencies. Almost all the border guards participating in the basic course expressed their wish to continue their language studies at an intermediate level. ${ }^{18}$

Taking into consideration the remarks from users of the basic-level tool, the tool Mid-Level English for Border Guards at Airports, with an improved interface, was created in 2012 and launched in 2013. The material in this tool covered a more advanced level of language (B2/C1) required by border guards in their daily tasks or joint operations coordinated by Frontex. It covered the topics Border Check, Security, Joint Operation and Communicating and the structure, methodology and instructions for use were similar to those of the basic-level tool.

These tools will be evaluated in more detail in the next part of this paper, together with the new generation of English for Border Guards courses developed by Frontex. At this point, I would like to note that the exercises corresponded to the practices of today's language teaching methodology. They were varied and efficient, although, with respect to the recommended order of working with them, it should be noted that according to the communicative approach to language teaching, it is not advised to study glossaries and lists of words before reading or listening to the texts in which they occur. Lexical items should be presented in context, even at a beginner level. Also, the recommendation for the user to listen to the dialogues - called 'audio and video scenarios' in the tools - and try to understand 'as much as possible', without systematic listening comprehension exercises to guide the learner and focus his/her attention on the target vocabulary, can be questioned.

\section{Going Online}

\section{CEPOL}

CEPOL's training activities of the last decade clearly illustrate the progress during which traditional forms of teaching and communication are increasingly replaced by easily accessible e-solutions. This process started with the launch of the Agency's website and electronic library storing the publications and studies of the leading law enforcement experts of the EU member states in the 2000s. By now, it has become a success story of how international training activities should be conducted in English. (Although these courses are not directly aimed at developing English for Law Enforcement skills, they use the specific-purpose language as a means for

17 Borszéki, J, The Principles of Modern Language Teaching Represented in an EU Training Tool for Border Guards II. Hadtudományi Szemle, 2014. Vol. 7, No. 2. pp. 106-122. Electronic source: www.epa.oszk.hu/02400/02463/00023/pdf/EPA02463_hadtudomanyi_ szemle_2014_02_106-122.pdf accessed: 30.07.2017)

18 Frontex: Mid-Level ..., op. cit., p. 1. 
conveying professional knowledge, similarly to Content and Language Integrated Learning [CLIL], therefore they should be mentioned here.) While in the 2000s, CEPOL residential activities (meetings, specific-purpose language training, further training courses, etc.) prevailed (See also Szabó ${ }^{19}$ ), their ratio within all the training activities has been significantly reduced. In 2017, CEPOL delivered 105 residential, 8 online courses and 95 webinars and maintained 34 online modules, developed by international teams of experts. ${ }^{20}$ Thus, we can say that today more than half of CEPOL's training activities are conducted through training modules and courses embedded in the Learning Management System and through webinars (in real time and also available in a recorded form). The numbers and ratios are even more spectacular if we look at the number of participants, shown in Figure 1.

\section{Figure 1. Participants of CEPOL courses in 2017}

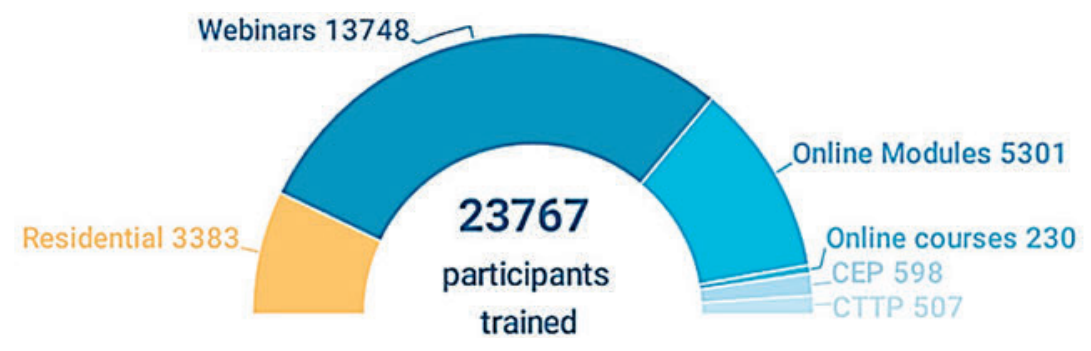

Source: $C E P O L^{21}$

Online training and learning solutions are ideal to cater for larger audiences and they allow self-paced learning. The year 2017 was the first when online courses were fully integrated into the training portfolios. Those courses were built on the content of residential activities, thus making the content more accessible. CEPOL delivered 79 training activities and provided eight online modules with a total number of 10,314 participants on topics involved in the EU Policy Cycle priorities, such as Migration, Cybercrime, Counter-terrorism, Strengthening the capacity to cooperate across borders and investigate crime effectively and efficiently, whilst guaranteeing the respect of fundamental rights, Information exchange and law enforcement cooperation, Investigation techniques, Public order: policing major events, and Fundamental rights. Apart from online courses modules and webinars, we should also mention the E-Net platform which supports the delivery of training and the creation of a knowledge repository of training curricula. In 2017, more features were made available to module users, including time-on task and content completion indicators, navigation through tags and downloadable certificates. ${ }^{22}$

19 Szabó A, Változások és új irányok az Európai Rendőrakadémia jövőjében, [in:] Hautzinger Z, Verhóczki J (Eds), Sodorvonalon. Tanulmányok Virányi Gergely 60. születésnapja tiszteletére. Budapest, 2012.

20 CEPOL: Annual Report of the European Union Agency for Law Enforcement Training (CEPOL), 2017. Electronic source: https://www.cepol.europa.eu/sites/default/files/Annual\%20 Report\%202017.pdf, accessed: 20.11.2020.

${ }^{21}$ Ibid., p. 10.

22 Ibid., pp. 19-22, 24. 
Since the 2000s, CEPOL has had two three-week residential Police English courses (entitled Language development: instruments and systems of European police cooperation - English, later Professional Law Enforcement terminology in English) every year, for more than a decade. In 2015, the pilot for the Police English Language (PEL) online course was launched, based on the learning content directly related to the topics of the CEPOL online learning modules. I had the opportunity to follow the pilot from the last phases of its preparation through its implementation to its evaluation. The participants were 55 students selected from the law enforcement staff from the EU Member States, with a minimum of 3 years of work experience, whose position and responsibilities required the use of the English language in the framework of cross-border police cooperation. This five-week distance learning, fully online course conducted through the CEPOL LMS was the first of its kind. The basic aim was to bring students with an A2 level knowledge of general English to a B1 level in specific-purpose Police English, including the development of speaking, reading, listening and writing skills as well as vocabulary and grammar needed in a professional context. Also, the course was meant to enhance international cooperation and establish relationships among the students to facilitate cross-border police cooperation in the future. The pilot course was built on a framework story and covered 9 professional topics (English Police Station, Equipment and Officers, Money Laundering, Cybercrime, Europol, Schengen, Counterterrorism, EU Policy Cycle and Joint Investigation Teams). ${ }^{23}$ Students worked on the learning material with the help of varied, task-based activities including individual, self-access, self-paced practice as well as real-time and asynchronous group work. The exercises demanded frequent consultations and keeping in touch continuously with the teachers and the other students, through the chatroom (forum) of the LMS as well as written and video messages. Thus, forming of an emotional environment of a course also became an important aspect in (language) learning. Observing communication among the students and teachers, I was delighted to see that a real virtual community was being created. Apart from the forum posts in which the students offered each other help and encouragement, it was touching to see the manifestations of sympathy with the French participants after the terrorist attacks in Paris.

I would also like to note the application of Wikis, a collaboration tool that is very useful in language teaching. The participants' task was to compile a monolingual thematic glossary together. Every week each student had to select and upload a definite number of new entries, most important words and expressions together with their definitions, to reinforce the knowledge of vocabulary learnt during the given week. These entries served as a basis for the weekly word tests held every Friday.

As much as $94 \%$ of the registered participants received a certificate of successful completion of the course. Based on the structured interview I made with one of the teachers in December 2015, I can summarise the lessons learnt from the course as follows:

The Moodle platform and the Poodl plugin combined with the CEPOL e-learning professional content (modules, courses etc.) proved to be helpful. However, in the

${ }^{23}$ CEPOL: Police English Language Online Course, Course Curriculum. (Working paper) Budapest: CEPOL, 2015. 
opinion of teachers, other platforms with better graphic design, easier to use and providing more interactivity to the students would be more suitable for language training. Some participants had frequent difficulties with the overall control of the LMS and faced technical problems, resulting in frustration and a large portion of communication with teachers was conducted only to discuss those technical issues. The course design needed simplification and the material had to be supplemented with more visual and listening content. The duration of 5 weeks over which a 25-hours-a-week study load was delivered proved too short to make sure that the students reach the next proficiency level. The teachers felt they needed more online hangouts with the students to get to know them better. They also believed that two teachers were not enough for the implementation of the course, considering the number of students and the number of assignments submitted by them from week to week. Also, they thought that more emphasis should be given to the role of teachers.

Overall, the pilot course proved successful. In the second edition of the Police English Language (PEL) online course (certified by the British Council), which took place in 2016 with longer study time, 72 participants and four teachers made use of the lessons learnt from the pilot session.

The year 2016 also saw the second edition of the Blended English Course for Police and Customs Cooperation Centres (hereinafter: PCCC) staff members. The course aimed at raising the English skills and terminology of the participants from B1 to B2 level and also improving their intercultural competencies, establishing relationships between various PCCCs and exchanging best practices. Since 2015, the course has been offered every year by the German Federal Police Academy in Lübeck in cooperation with CEPOL. The 6-month course combines e-learning elements, very similar to those of the aforementioned PEL course on the CEPOL platform, and makes use of the PCCC Module on the CEPOL E-net with three residential 'presence phases', where one-week classroom practice with English teachers is provided at the Police Academies of various member states, as well as visits to PCCCs. ${ }^{24}$ The syllabus exploits all these elements very efficiently. For example, the students do guided online work in three groups to gain knowledge about three different topics related to the PCCCs and police cooperation in the $\mathrm{EU}$ and during the following presence phase they give presentations to other groups about their topic. One of the trainers gave a thorough account of the course in a webinar, saying that online, task-based practice at the courses is organised so well that the teachers feel they are together with the students all the time, not only during the presence phases. The ratio of students and teachers is more favourable than in the case of the PEL course (two trainers for 12 to 15 students). The course is tailored to the specific needs of the students, with a special focus on frequently used channels of communication such as telephone conversations and online correspondence. ${ }^{25}$

${ }^{24}$ CEPOL: Project: PCCC Blended English Language Course 2016. Electronic source: https:// enet.cepol.europa.eu/index.php?id=online-courses\&no_cache=1, accessed: 20.11.2020.

${ }_{25}$ CEPOL: PCCC: Module and Blended English Language Course. (webinar, recorded 31. 03. 2017) Electronic source: https://enet.cepol.europa.eu/index.php?id=webinars0\&no_ cache $=1$, accessed: 20.11 .2020 . 


\section{Frontex}

In the last few years, training courses delivered by Frontex (Cf. Szabóz6), too, have undergone significant changes in terms of technology. The Virtual Aula was set up as an online platform, now including the Frontex LMS, among other features. Similarly to CEPOL, Frontex provides an opportunity for specialists in all sectors of border management to join training courses, many of which are delivered fully or partially online. According to the Agency's Training webpage, 'An ICT platform and eLearning solutions are considered of strategic importance, as they are targeting costeffective ways to increase capabilities of Frontex, as well of its stakeholders.' While the Frontex Annual Activity Report $2016^{27}$ names only two online supplements to courses delivered by the Training Unit ${ }^{28}$, out of the 43 courses showcased in the 2018 Course Catalogue ${ }^{29} 3$ require an online entry test, 4 are conducted online only and 13 are blended courses comprising individual online learning phases and contact phases. As formulated by the Training Unit, courses designed today 'generally adopt a blended learner-centred approach and are composed of distance on-line learning and face to face learning.${ }^{30}$ Webinars have also been used since 2016 for conveying knowledge. In 2018, there were 3 webinars a month on average functioning as parts of courses, awareness-raising presentations or virtual workshops.

One of the courses available only on the Frontex LMS is the English Language Course for Border and Coast Guards - Level 1 (ELCBCG) online course, launched in October 2018. Its development started in 2015. I was also a member of the international working group of border guards and English teachers with several years' experience in the field, designated by Frontex for the development of the learning material. The aim was to provide a language course similar to the Basic and Mid-level English for Border Guards at Airports tool but with a widened scope (to be used by border guards at all types of borders) and applying the most current and high-level IT technology. The target group are the officers responsible for performing first-line checks and border surveillance, with an A2/B1 level of English, who want to develop their English skills in professional contexts to be able to conduct more efficient communication with customers and foreign colleagues. The course is self-paced and is available on both desktop computers and ubiquitous devices, i.e. laptops, tablets and smartphones with mobile technology allowing flexibility

${ }^{26}$ Szabó A, Training opportunities in law enforcement (CEPOL, MEPA, FRONTEX), [in:] Szabó A, Zsambokiné, Ficskovszky Á (Eds) Az adó- és vámszolgálatok aktuális kihívásai. Konferencia és tanulmánykötet. Budapest: Magyar Rendészettudományi Társaság Vám- és Pénzügyőri Tagozat, 2015, pp. 177-196.

27 Council of the European Union (2017): Frontex Annual Activity Report 2016, Brussels, 20 July 2017 (OR. en) 11442/17 Electronic source: http://www.statewatch.org/news/2017/aug/ eu-frontex-activity-report-2016.pdf, accessed: 20.11.2020.

${ }^{28}$ Intermediate Training on ABC systems for First Line Officers and Specialised Training on Vulnerability Assessment and Testing for ABC systems.

${ }^{29}$ Frontex: COURSE CATALOGUE 2018. Electronic source: https://publications.europa.eu/ en/publication-detail/-/publication/c7386699-5e35-11e8-ab9c-01aa75ed71a1/language-en, accessed: 20.11.2020.

30 Frontex: Frontex training Newsletter 2018 III. Electronic source: https://aula. frontex.europa.eu/courses/pluginfile.php/23/mod_forum/attachment/8714/TRU_Newsletter_03-2018_WEB2.pdf, accessed: 20.11.2020. 
to study both on- and offline. As the course is integrated into the Frontex LMS, the offline usage history of users is stored and updated immediately when they go online again. Using this learning analytics feature, teachers who create a virtual classroom for their students can trace their learning patterns and tailor it accordingly when using the course as part of blended training.

The structure is based on four modules. The first one contains general knowledge useful at all three types of borders, while the second, third and fourth modules provide learning material directly concerning the air, land and sea borders, respectively. Each module is broken down into units and subunits. They cover similar topics to the ones in the Basic EBGA tool, including the typical situations related to first-level border checks and border surveillance, including the border guards' special tasks and equipment. Similarly to the English tools for border guards at airports, the most important vocabulary items are introduced at the beginning of each unit but in this case, audio and visual help is provided for the learner to understand and learn relevant terminology. The course is built on a framework story, according to which the user plays the role of an experienced border guard helping a colleague to understand the texts of the dialogues (scenarios) that they come across in various professional situations reflecting their daily work. This contextualised feature facilitates 'situated learning' (See: Sica et al. ${ }^{31}$ and Ürmösné Simon ${ }^{32}$ ). Language practice is more consistent than in the tools for border guards at airports; understanding is helped by a listening comprehension exercise accompanying each scenario. Also, after each subunit, learners are given an opportunity to practise new terminology and consolidate its proper use in vocabulary tests. Once the learners have completed all modules and exercises, they can check their progress in the Assessment section, which provides a formal evaluation of the skills acquired.

The usage of the tool is restricted to the law enforcement staff. To register in the Frontex learning environment and access this course, learners must be members of a border or coast guard organisation or some other law enforcement organisation with border-related responsibility.

The course is a spectacular step forward from the English tools for border guards at airports, not only due to the abovementioned progress from a methodological and technological perspective but also in terms of graphic design and appearance. This is thanks to the application of an authoring tool, which will be also used in ELCBCG Level 2, the course now being developed by the same working group, for border guards with B2/C1 level of English, working in the second line of border control or involved in the joint operation.

The aspect I would especially like to emphasize in the development of the showcased Frontex English courses is the way the aforementioned scenarios have been created. During the first phase of designing these courses, experienced border

31 Sica L.S, Veneri A.D, Miglino O, Exploring New Technological Tools for Education: Some Prototypes and Their Pragmatical Classification, Methodologies, Tools and New Developments for E-Learning, [in:] Pontes E (Ed.), InTechOpen. Electronic source: http:// www.intechopen.com/books/methodologies-tools-and-new-developments-for-e-learning/ exploring-newtechnological-tools-for-education-some-prototypes-and-their-pragmaticalclassification, accessed: 03.11.2020.

32 Situated learning is essential in the traditional forms of English for Law Enforcement training, too. See: Ürmosné Simon G, Technical English for Officers. Budapest, 2018, pp. 7-18. 
guards deployed at the various types of borders are invited to produce dialogues they regularly have in English during work and to make lists of vocabulary they use in typical professional situations. Thus, as opposed to the 'traditional', 'top-down', questionnaire-based needs analyses for language courses conducted by language teachers that often focus on linguistic forms and gather data about the learner and not from the learner, in this case, focus is on the discourse and communicative events, using a 'bottom-up' approach. (See Borszéki33) This kind of needs analysis is also task-based because the situations are built on the everyday activities of border guards, which can be performed with success only if the guards use their English language skills appropriately and efficiently. In this way, the working group developing the language course (i.e. the exercises that help users to learn the language presented in the scenarios) gains the same corpora that we would gather using the CEF Professional Profile ${ }^{34}$, by visiting border crossing points, listening to and recording or noting down border guards' conversations, which would be a lengthy process, and, due to security considerations, is actually not feasible for teachers who are not members of the professional law enforcement staff.

\section{Conclusions}

\section{Language teaching methodology and technical limitations}

The abovementioned Frontex tools and those used in the CEPOL online courses for teaching English are examples of instructional media described in the CEFR. ${ }^{35}$ Users apply them in an individual self-instructional mode, by (guided) self-study, pursuing negotiated self-directed objectives. Learning is facilitated by a combination of conscious learning and sufficient practice. Learners are expected to learn by direct exposure to the authentic target language, such as specially selected spoken utterances and written texts ('intelligible input'), and by direct participation in specially devised and constructed tasks ('comprehensible output'). They are exposed to spoken and written texts, ensuring that new material is intelligible by inference from the verbal context, with comprehension monitored and ensured by exercises. Learners are expected or required to learn by simple participation in tasks and activities with precisely defined goals, input and outcomes. Teaching lexis is of key importance for these tools. Their authors select keywords and phrases in thematic areas required for the achievement of communicative tasks relevant to learner needs and also (authentic) spoken texts to teach terminology

${ }^{33}$ Borszéki, J, The Definition of Specific-Purpose English Language Competences Needed in Border Control and Their Development Potentials. I. The Issues of Defining Specific-Purpose Language Competences. Magyar Rendészet, 2017, Issue 4, pp. 128-131. Electronic source: https://folyoiratok.uni-nke.hu/document/nkeszolgaltato-uni-nke-hu/Magyar_Rendeszet_2017_04_online.pdf, accessed: 3.11.2020.

${ }^{34}$ Huhta M, et al., Needs Analysis for Language Course Design: A Holistic Approach to ESP. Cambridge: Cambridge University Press, 2013, pp. 9-52.

${ }^{35}$ Council of Europe: Common European Framework of Reference for Languages..., op. cit., p. 141. 
they contain. Learners are expected to develop their vocabulary in a variety of ways, also listed in the CEFR, such as simple exposure to words and fixed expressions used in authentic spoken and written texts, through inclusion in context and thematic (in certain cases bilingual) word lists, recycling in exercises that require gap-filling, sentence construction, filling in crossword puzzles, matching phrases and doing true/false, single and multiple choice quizzes, etc.

These tools mainly develop receptive and reproductive skills, because this type of self-study tool has its limitations. We like to call it interactive, but this only means that the learners are not merely passive spectators of the material; they conduct interaction with the tool through Human Computer Interface. ${ }^{36}$ Generally speaking, they respond to questions provided by the programme, i.e. react to stimuli after understanding and memorising a certain amount of input. Language teaching CD-ROMs, DVDs and online courses that do not involve constant monitoring by a tutor do not differ from each other technologically or in terms of methodology. Basically, they are programmed learning devices (very often with a linear syllabus) with materials constructed according to a predetermined scheme and arranged in appropriate steps. ${ }^{37}$ It is obvious that they are not suitable for developing all communicative language competencies. For example, spoken and written production cannot be intensively practiced with them. E-learning tools do not include open-ended tasks; the answers must be predictable so that the programme can provide immediate feedback to all the answers.

The communicative approach to (e.g.. teacher-assisted, classroom) language learning traditionally defines three phases of teaching-learning process, such as Presentation, Practice and (independent) Production or free practice (PPP) ${ }^{38}$. The users of the e-learning tools in question will only cover the first two phases. During practice, they can solve what we call pre-communicative, structured tasks, i.e. an activity also referred to as scaffolding. In our case, the exercises included in this phase focus on helping learners memorise terminology and are very efficient for this purpose. However, they do not provide an opportunity for the learners to finish the process within the framework of the tool, i.e. to use the acquired 'passive' knowledge independently, in real interaction. Police officers and border guards who use English on a daily basis can make this happen during their everyday work. In their case, it is the achievements in real-life communication (i.e. whether they reach their pragmatic and other purposes) that will show whether they have actually managed to develop their language skills. Such achievements may have a very

${ }^{36}$ Dzandu M, Tang Y, Beneath a learning management system - Understanding the human information interaction in information systems. 6th International Conference on Applied Human Factors and Ergonomics (AHFE 2015) and the Affiliated Conferences, AHFE 2015, Procedia Manufacturing. Electronic source: https://ac.els-cdn.com/S2351978915002401/1-s2.0-S2 351978915002401-main.pdf?_tid=b0d24fb4-9f24-4c53-8cb9-64699fdf0f56\&acdnat $=154300$ 5334_d796e216a0eae6f15b0a813a823d1db3, accessed:20.11.2018, p. 1950.

${ }^{37}$ In fact, such a linear syllabus has an important role in language teaching, as the elements of the learning material must be introduced in order of difficulty.

${ }^{38}$ This is increasingly challenged nowadays, e.g. by the task-based approach, which claims that these phases should be applied more flexibly, including more active involvement of the learners, and that the steps should be defined rather as e.g. Pre-task, Task, Planning, Report, Analysis and Practice. 
strong motivational force and the learners' feeling that they can cooperate with customers or colleagues more easily and efficiently will lead to their more confident professional presence. However, proper linguistic feedback to productive activities and professional correction of mistakes can only be provided by an English teacher, in simulations that resemble real-life situations and also involve the essential unexpected elements typical of real communication. (See also Borszéki ${ }^{39}$ ) Therefore, comprehensive foreign language training that also aims to develop speaking skills definitely requires the presence of a teacher, at least during certain phases of the process. To achieve this, the aforementioned CEPOL PEL course or the blended learning forms, such as the CEPOL PCCC training, seem to be more suitable.

\section{Development in course design}

The ICT tools designed to be used without the virtual or real presence of a teacher have their advantages, as the learners can move ahead at their own pace, in their own learning style, the programme gives instant feedback, they can easily monitor their own progress, the learning material is comprehensive, varied, its structure is obvious and clear and the user interface is aesthetic and easily manageable. As opposed to residential or traditional classroom courses, they provide greater time flexibility and are more economical in terms of resources (finance, staff etc.).

The new features introduced in online ICT courses embedded in learning management systems can connect learners, making it possible for them to engage in activities that require cooperation, which is an essential element in modern training courses. As mentioned earlier, courses embedded in LMS also have progress tracking functions and gamification elements, which can be very helpful and motivating for the learners. ${ }^{40}$

As students' evaluations of the efficiency of various English language courses mentioned in this paper are not available, I decided to make an empiric comparison of their features. (See Table 1.) For this, I have chosen a new framework from the many available. The Rubric for Evaluating E-Learning Tools in Higher Education ${ }^{41}$ is based on extensive research and it integrates the existing concepts used for evaluating e-learning tools. The versatile aspects it contains are easily adaptable and make the framework suitable for the abovementioned purpose. The main categories can be briefly defined as follows: ${ }^{42}$

Functionality:

Accessibility:

Technical category: Mobile Design:
Is the tool suitable for the intended purpose?

Does it have an adaptable curriculum design to support multiple learning approaches?

What basic technologies are needed to make it work?

Can it be comfortably used on mobile devices?

39 Borszéki, J, The Principles ..., op. cit., pp. 106-122.

40 Sica L.S, Veneri A.D, Miglino O, p. 117.

${ }^{41}$ Anstey L, Watson K, A Rubric for Evaluating E-Learning Tools in Higher Education. EDUCASE Review, September 10, 2018. Electronic source: https://er.educause.edu/articles/2018/9/ a-rubric-for-evaluating-e-learning-tools-in-higher-education, accessed: 30.07.2020.

42 lbid. 
Privacy, Data

Protection and Rights:

Social Presence:

Teaching Presence:

Cognitive Presence:
Is the users' personal information or intellectual property at risk?

Does it create and sustain a sense of community among learners?

Are there any elements related to the tool that enable instructors to establish and maintain their teaching presence?

Can the tool support students' cognitive engagement in learning tasks?

Due to the length limits of this paper, I used only those subcategories from the Rubric that applied to the examined tools. The table contains shortened descriptions of ideal features in each category and indicates whether the given course meets the mentioned criterion or not. (It goes without saying that in the case of a blended course, CEPOL PCCC, the statements only refer to the e-learning elements.) As the tools/courses compared here were/are meant to teach English, I also considered it important to add the aspects relevant to language teaching/learning in a separate section.

Table 1. Rubric for the evaluation of the ESP e-learning tools developed by Frontex and CEPOL

\begin{tabular}{|c|c|c|c|c|c|}
\hline & Features & 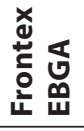 & 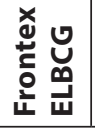 & 옴 & 엄 \\
\hline Functionality & & & & & \\
\hline Scale & $\begin{array}{l}\text { Can accommodate any size of learning } \\
\text { group (flexibility to create subgroups). }\end{array}$ & - & -43 & + & + \\
\hline Ease of use & User-friendly interface & + & $+{ }^{44}$ & + & + \\
\hline Hypermediality & $\begin{array}{l}\text { Users can communicate through various } \\
\text { channels (audio, visual, text); } \\
\text { Non-linear engagement with the } \\
\text { material. }\end{array}$ & - & - & + & + \\
\hline Accessibility & & & & & \\
\hline $\begin{array}{l}\text { Accessibility } \\
\text { standards }\end{array}$ & e.g.. W3C WCAG 2.0 & - & - & - & - \\
\hline $\begin{array}{l}\text { User-focused } \\
\text { participation }\end{array}$ & $\begin{array}{l}\text { Addresses diverse users with various } \\
\text { literacies and capabilities. }\end{array}$ & + & + & + & + \\
\hline $\begin{array}{l}\text { Required } \\
\text { equipment }\end{array}$ & $\begin{array}{l}\text { Typically available equipment is enough } \\
\text { to use it. }\end{array}$ & + & + & + & + \\
\hline Cost of use & All features can be used free of charge. & + & + & + & + \\
\hline
\end{tabular}

${ }^{43}$ Only if used by a teacher in the LMS.

${ }^{44}$ Here we need to emphasize the professional, attractive graphic design, which makes this tool unique as compared with three other courses. 


\begin{tabular}{|c|c|c|c|c|c|}
\hline \multicolumn{6}{|c|}{ Technical category } \\
\hline $\begin{array}{l}\text { Embedding } \\
\text { within an LMS }\end{array}$ & $\begin{array}{l}\text { Can be embedded or fully integrated } \\
\text { while maintaining full functionality. }\end{array}$ & - & + & + & + \\
\hline $\begin{array}{l}\text { Desktop/Laptop } \\
\text { Operating } \\
\text { Systems }\end{array}$ & $\begin{array}{l}\text { Can be used effectively with any } \\
\text { standard, up-to-date operating system. }\end{array}$ & + & + & + & + \\
\hline Browser & $\begin{array}{l}\text { Can be used effectively with any } \\
\text { standard, up-to-date browser. }\end{array}$ & - & + & + & + \\
\hline $\begin{array}{l}\text { Additional } \\
\text { Downloads }\end{array}$ & $\begin{array}{l}\text { No need to download additional } \\
\text { software or browser extensions. }\end{array}$ & + & + & + & + \\
\hline \multicolumn{6}{|l|}{ Mobile Design } \\
\hline Access & $\begin{array}{l}\text { The tool can be accessed, regardless } \\
\text { of the mobile operating system and } \\
\text { device. The design of the mobile tool } \\
\text { fully takes into consideration the } \\
\text { constraints of a smaller-sized screen. }\end{array}$ & - & + & $n / a^{45}$ & $\mathrm{n} / \mathrm{a}$ \\
\hline Functionality & $\begin{array}{l}\text { There is little to no functional difference } \\
\text { between the mobile and the desktop } \\
\text { version, regardless of the device used } \\
\text { to access it. No difference in functionality } \\
\text { between apps designed for different } \\
\text { mobile operating systems. }\end{array}$ & - & + & $\mathrm{n} / \mathrm{a}$ & $\mathrm{n} / \mathrm{a}$ \\
\hline Offline Access & $\begin{array}{l}\text { Offers an offline mode: Core features } \\
\text { of the tool can be accessed and } \\
\text { utilized even when offline, maintaining } \\
\text { functionality and content. }\end{array}$ & - & + & $\mathrm{n} / \mathrm{a}$ & $\mathrm{n} / \mathrm{a}$ \\
\hline \multicolumn{6}{|c|}{ Privacy, Data Protection and Rights } \\
\hline $\begin{array}{l}\text { Sign Up/ } \\
\text { Sign In }\end{array}$ & $\begin{array}{l}\text { Use of the tool does not require } \\
\text { the creation of an external account } \\
\text { or additional login. }\end{array}$ & $\begin{array}{c}\text { not } \\
\text { appli- } \\
\text { cable }\end{array}$ & + & + & + \\
\hline Data Privacy & $\begin{array}{l}\text { Users can keep data private and decide } \\
\text { if / how data is to be shared. }\end{array}$ & $\begin{array}{l}\text { not } \\
\text { appli- } \\
\text { cable }\end{array}$ & + & + & + \\
\hline $\begin{array}{l}\text { Archiving, } \\
\text { Saving, and } \\
\text { Exporting Data }\end{array}$ & $\begin{array}{l}\text { Users can archive, save, or import and } \\
\text { export content or activity data in a } \\
\text { variety of formats. }\end{array}$ & - & + & + & + \\
\hline \multicolumn{6}{|l|}{ Social Presence } \\
\hline Collaboration & $\begin{array}{l}\text { The tool can support a community } \\
\text { of learning through both asynchronous } \\
\text { and synchronous opportunities for } \\
\text { interactivity between users. }\end{array}$ & - & -46 & + & + \\
\hline
\end{tabular}

${ }^{45}$ The CEPOL tools can be used on e.g. tablets but the CEPOL LMS and e-learning modules were originally not designed to be used on mobile phones as the Frontex ELBCG was.

${ }^{46}$ Only if used by a teacher in the LMS. 


\begin{tabular}{|c|c|c|c|c|c|}
\hline $\begin{array}{l}\text { User } \\
\text { Accountability }\end{array}$ & $\begin{array}{l}\text { Instructors can control learner } \\
\text { anonymity; the tool provides technical } \\
\text { solutions for holding learners } \\
\text { accountable for their actions. }\end{array}$ & - & - & + & + \\
\hline \multicolumn{6}{|c|}{ Teaching Presence } \\
\hline Facilitation & $\begin{array}{l}\text { The tool has easy-to-use features } \\
\text { that would significantly improve } \\
\text { an instructor's ability to be present } \\
\text { with learners via active management, } \\
\text { monitoring, engagement and feedback. }\end{array}$ & - & - & + & + \\
\hline Customization & $\begin{array}{l}\text { The tool is adaptable to its environment: } \\
\text { easily customized to suit the classroom } \\
\text { context and targeted learning outcomes. }\end{array}$ & - & - & - & - \\
\hline $\begin{array}{l}\text { Learning } \\
\text { Analytics }\end{array}$ & $\begin{array}{l}\text { The instructor can monitor learners' } \\
\text { performance on a variety of responsive } \\
\text { measures. These measures can } \\
\text { be accessed through a user-friendly } \\
\text { dashboard. }\end{array}$ & - & -47 & + & + \\
\hline \multicolumn{6}{|c|}{ Cognitive Presence } \\
\hline $\begin{array}{l}\text { Higher-Order } \\
\text { Thinking }\end{array}$ & $\begin{array}{l}\text { The use of the tool easily facilitates } \\
\text { learners to exercise higher-order } \\
\text { thinking skills. }\end{array}$ & + & + & + & + \\
\hline $\begin{array}{l}\text { Metacognitive } \\
\text { Engagement }\end{array}$ & $\begin{array}{l}\text { Through the tool, learners can regularly } \\
\text { receive formative feedback on learning } \\
\text { (i.e. they can track their performance, } \\
\text { monitor their improvement and test their } \\
\text { knowledge). }\end{array}$ & $(+)^{48}$ & + & + & + \\
\hline
\end{tabular}

\begin{tabular}{|l|c|c|c|c|}
\hline \multicolumn{5}{|c|}{ Targeted communicative skills and linguistic areas } \\
\hline Listening comprehension & + & + & + & + \\
\hline Reading comprehension & + & + & + & + \\
\hline Speaking & - & - & + & + \\
\hline Writing & - & -49 & + & + \\
\hline Vocabulary (terminology) & + & + & + & + \\
\hline Grammar & - & - & + & - \\
\hline
\end{tabular}

Source: Author's own elaboration, based on Anstey - Watson. ${ }^{50}$

${ }^{47}$ See previous footnote. This concerns all the criteria mentioned under this heading.

${ }^{48}$ Feedback is provided only after each solved exercise.

${ }^{49}$ The user has to type in the answers, but as there are no open-ended tasks, the maximum length of these written texts is a sentence, strictly defined by the stimulus, which cannot be considered independent usage or written production.

50 Anstey L, Watson K, op. cit. 
In summary, I think that I have managed to prove the initial hypothesis. It can be stated that the starting point of the process was to recognise the need for common tools in the EU in the area of teaching English. The development can be traced, in terms of technology, from the portable data carriers and 'quasiinteractive' tools to the internet-based platforms and learning management systems, also accessible through mobile devices. Technological development also facilitated easier and more efficient dissemination of the tools/courses for the targeted learning groups. Interestingly, in terms of methodology, the growing range of technical possibilities contributed not only to the larger freedom of users as to where, when and how they want to learn but also to the greater number of opportunities to combine self-access e-learning with partially or fully teachermonitored forms of tuition, similar to general trends in educational technology, ${ }^{51}$ applying, for example, blended learning. The latest features of the outlined CEPOL and Frontex courses that enable users to do task-based exercises in groups also reflect a shift from the traditional direct instruction method to the constructivist approach and connectivism.

Law enforcement training courses aim at developing practical skills and competencies and so are specific-purpose English courses. Therefore, the process outlined in this paper is a series of logical steps to make the acquisition of these competencies even more efficient.

Having been a language teacher for several decades, I have seen several new educational devices, technologies and methodologies declared to be omnipotent which turned out to be fads. ICT and e-learning tools and courses are here to stay and seem to indicate a paradigm shift. New developments in this field will definitely be reflected in the e-learning tools used for teaching English for Law Enforcement in the future, too.

\section{References}

1. Anstey L, Watson K, A Rubric for Evaluating E-Learning Tools in Higher Education. Electronic source: https://teaching.uwo.ca/pdf/elearning/Rubric-for-eLearning-Tool-Evaluation.pdf, accessed: 30.07.2018.

2. Anstey L, Watson K, A Rubric for Evaluating E-Learning Tools in Higher Education. EDUCASE Review, September 10, 2018. Electronic source: https:// er.educause.edu/articles/2018/9/a-rubric-for-evaluating-e-learning-tools-in-hi gher-education

3. Borszéki J, A Rendőrség határrendészeti feladatokat ellátó állományának idegen nyelvi ismeretei és érdeklődése a nemzetközi határrendészeti tevékenységek iránt [The foreign language skills of the border policing staff of the Police and their interest in international border policing activities], [in:] Szelei I, Berki G (Eds), A hadtudomány és a 21. század, Tanulmánykötet. Budapest, 2015.

4. Borszéki J, The Definition of Specific-Purpose English Language Competences Needed in Border Control and Their Development Potentials. I. The Issues

\footnotetext{
51 Dzandu, M — Tang, Y: Beneath a learning management system ..., op.. cit. p. 1947.
} 
of Defining Specific-Purpose Language Competences, Magyar Rendészet, 2017, Issue 4. Electronic source: https://folyoiratok.uni-nke.hu/document/nkeszolgaltato-uni-nke-hu/Magyar_Rendeszet_2017_04_online.pdf

5. Borszéki J, The Principles of Modern Language Teaching Represented in an EU Training Tool for Border Guards II. Hadtudományi Szemle, Vol. 7, No. 2. Electronic source: www.epa.oszk.hu/02400/02463/00023/pdf/EPA02463_hadtudom anyi_szemle_2014_02_106-122.pdf

6. Borszéki J, Training border policing experts in English for specific purposes (ESP): Uniform trends in EU member states, [in:] Kaljula D (Ed.), Sisekaitseakadeemia Teadusartiklid: Valikkogu. Tallinn, 2016.

7. CEPOL: Annual Report of The European Union Agency for Law Enforcement Training (CEPOL) 2017. Electronic source: https://www.cepol.europa.eu/sites/def ault/files/Annual\%20Report\%202017.pdf

8. CEPOL: European Training Scheme: Mapping of Law Enforcement Training in the European Union - Management Summary. Electronic source: https:// enet.cepol.europa.eu/fileadmin/documents/LETS/LETS_Management_Summ ary.pdf

9. CEPOL: PCCC: Module and Blended English Language Course. (webinar, recorded 31. 03. 2017) Electronic source: https://enet.cepol.europa.eu/index. php?id=webinars0\&no_cache $=1$

10. CEPOL: Police English Language Online Course, Course Curriculum. (Working paper) Budapest, CEPOL, 2015.

11. CEPOL: Project: PCCC Blended English Language Course 2016. Electronic source: https://enet.cepol.europa.eu/index.php?id=online-courses\&no_cache=1

12. Council of Europe: Common European Framework of Reference for Languages: Learning, Teaching, Assessment. Electronic source: https://rm.coe.int/16802fc1 bf, accessed 10.10.2018.

13. Council of the European Union: Frontex Annual Activity Report 2016, Brussels, 20 July 2017 (OR. en) 11442/17. Electronic source: http://www.statewatch.org/ news/2017/aug/eu-frontex-activity-report-2016.pdf

14. Dzandu M, Tang Y, Beneath a learning management system - Understanding the human information interaction in information systems. 6th International Conference on Applied Human Factors and Ergonomics (AHFE 2015) and the Affiliated Conferences, AHFE 2015, Procedia Manufacturing. Electronic source: https://ac.els-cdn.com/S2351978915002401/1-s2.0-S23519789150024 01-main.pdf?_tid=b0d24fb4-9f24-4c53-8cb9-64699fdf0f56\&acdnat=15430053 34_d796e216a0eae6f15b0a813a823d1db3

15. European Commission: Communication from the Commission to The European Parliament, The Council, The European Economic and Social Committee and The Committee of The Regions: Establishing a European Law Enforcement Training Scheme (COM/2013/0172 final). Electronic source: https://eur-lex.europa.eu/ LexUriServ/LexUriServ.do?uri=COM:2013:0172:FIN:EN:PDF

16. European Commission: European Agenda on Security $\operatorname{COM(2015)~} 185$ final. Electronic source: https://ec.europa.eu/home-affairs/sites/homeaffairs/files/e-library /documents/basic-documents/docs/eu_agenda_on_security_en.pdf

17. Frontex: Basic English for Border Guards at Airports, Introduction, 2011. (electronic teaching material on $C D$ ). 
18. Frontex: COURSE CATALOGUE 2018. Electronic source: https://publications.euro pa.eu/en/publication-detail/-/publication/c7386699-5e35-11e8-ab9c-01aa75e d71a1/language-en

19. Frontex: Frontex training Newsletter 2018 III. Electronic source: https://aula.front ex.europa.eu/courses/pluginfile.php/23/mod_forum/attachment/8714/TRU_N ewsletter_03-2018_WEB2.pdf

20. Frontex: Mid-Level English for Border Guards at Airports, Instruction Booklet, 2013. (electronic teaching material on DVD).

21. Huhta M et al., Needs Analysis for Language Course Design: A Holistic Approach to ESP. Cambridge, 2013.

22. Kovács G, The Hungarian law enforcement education system at the National University of Public Service: the best practice of Hungary. European Police Science And Research Bulletin, 2017, Vol. 3, pp. 93-99.

23. Kovács G, The practice-oriented training and education system at the National University of Public Service: The common public service practice. Belgrade: Academy of Criminalistic and Police Studies, 2015.

24. Magasvári A, What is a good entrant into the labour market? The expectations of the National Tax and Customs Administration, Tudásmenedzsment, 2018, Issue 2. Electronic source: http://btk.pte.hu/sites/btk.pte.hu/files/files/xix.evf_.2. szam_.pdf

25. Pielmus C. G, Innovation in Teaching English for Law Enforcement: A Technology-Integrated Approach, Society. Integration. Education. Proceedings of the International Scientific Conference, 2018, Vol. 3. Electronic source: http://journals.rta.lv/ index.php/SIE/article/view/3074/3102

26. Sica L.S, Veneri, A.D, Miglino O, Exploring New Technological Tools for Education: Some Prototypes and Their Pragmatical Classification, Methodologies, Tools and New Developments for E-Learning, [in:] Dr. Elvis Pontes (Ed.), InTechOpen, Electronic source: http://www.intechopen.com/books/methodologies-toolsand-new-developments-for-e-learning/exploring-newtechnological-tools-foreducation-some-prototypes-and-their-pragmatical-classification

27. Szabó A, Training opportunities in law enforcement (CEPOL, MEPA, FRONTEX), [in:] Szabó A, Zsambokiné, Ficskovszky Á (Eds) Az adó- és vámszolgálatok aktuális kihívásai. Konferencia és tanulmánykötet. Budapest: Magyar Rendészettudományi Társaság Vám- és Pénzügyőri Tagozat, 2015, pp. 177-196.

28. Szabó A, Változások és új irányok az Európai Rendőrakadémia jövőjében, [in:] Hautzinger Z, Verhóczki J (Eds), Sodorvonalon. Tanulmányok Virányi Gergely 60. születésnapja tiszteletére. Budapest, 2012.

29. Ürmosné Simon G, Technical English for Officers. Budapest, 2018.

30. Ürmösné Simon G, The traits and the thrill of serial killers. Internal Security, 2015, Vol. 7, Issue 2.

\section{About the Author}

Judit Borszéki, PhD, teacher. Place of employment: National University of Public Service, Faculty of Law Enforcement. Research interests:Developing EFL (English as a Foreign Language) competences needed in international law enforcement cooperation. E-mail: borszeki.judit@uni-nke.hu 
Streszczenie. Działaniom międzynarodowym (operacyjnym i szkoleniowym) prowadzonym przez funkcjonariuszy organów ścigania towarzyszy coraz większa świadomość tego, że niezbędne jest sprawne porozumiewanie się osób w nich uczestniczących w jednym wspólnym języku, angielskim. Jednakże nawet $w$ ciągu ostatnich kilku lat w międzynarodowych dokumentach zawodowych i prawnych wielokrotnie podkreślano braki w znajomości języków obcych przez funkcjonariuszy organów ścigania oraz potrzebę dalszych szkoleń w tym zakresie (chodzi głównie o język angielski). Fakt, że specjalistyczne kursy języka angielskiego nadal stanowiq ważne elementy programów nauczania zarówno krajowych instytucji szkoleniowych w zakresie egzekwowania prawa, jak i dwóch największych agencji UE zajmujacych się szkoleniem funkcjonariuszy policji, a także straży granicznej i przybrzeżnej (CEPOL i Frontex), dowodzi, że problem ten nadal istnieje. Wykorzystując badania jakościowe oraz przedstawiając przegląd i ocenę najważniejszych trendów e-learningowych i narzędzi wykorzystywanych w nauczaniu języka angielskiego dla potrzeb egzekwowania prawa przez (EPOL i Frontex w ostatniej dekadzie, artykuł omawia postępy poczynione w tej dziedzinie zarówno pod względem jakości, jak i metodologii. Autor przedstawia ograniczenia techniczne niektórych narzędzi e-learningowych i wskazuje na uświadomienie sobie przez twórców kursów, że wirtualna lub rzeczywista obecność nauczyciela jest niezbędna w kursach językowych.

Zusammenfassung. Mit den internationalen (Einsatz- und Ausbildungs-) Aktivitäten der Strafverfolgungsbehörden wächst die Einsicht, dass es für die Beteiligten unerlässlich ist, sich effizient in einer gemeinsamen Sprache, hauptsächlich Englisch, zu verständigen. Aber auch in den letzten Jahren wurde in internationalen Fach- und Rechtsdokumenten mehrfach auf die Lücken in den Fremdsprachenkenntnissen der Angehörigen der Strafverfolgungsbehörden und die Notwendigkeit weiterer Fremdsprachenkurse (hauptsächlich Englisch) hingewiesen. Die Tatsache, dass spezielle Englischkurse nach wie vor wichtige Bestandteile der Lehrpläne sowohl der nationalen Ausbildungseinrichtungen für Strafverfolgungsbeamte als auch der beiden größten EU-Agenturen für die Ausbildung von Polizeibeamten sowie von Grenz- und Küstenwächtern (CEPOL und Frontex) sind, beweist, dass dieses Problem nach wie vor besteht. Auf der Grundlage der qualitativen Forschung und mit Hilfe eines Überblicks und einer Bewertung der wichtigsten E-Learning-Trends und -Tools, die von CEPOL und Frontex in den letzten zehn Jahren beim Unterrichten von Englisch für Strafverfolgungsbeamte eingesetzt wurden, erörtert das vorliegende Artikel die Fortschritte, die in diesem Bereich in Bezug auf Qualität und Methodik erzielt wurden. Es zeigt die technischen Grenzen bestimmter E-LearningTools auf und verweist auf die daraus resultierende Erkenntnis der Kursentwickler, dass die virtuelle oder reale Anwesenheit des Lehrers in Sprachkursen unerlässlich ist.

Резюме. Международная (оперативная и учебная) деятельность, осуществляемая сотрудниками правоохранительных органов, связана с растущим пониманием необходимости эффективного общения сотрудников на одном общем языке - английском. В течение последних нескольких лет в международных профессиональных и правовых документах неоднократно отмечались недостатки в знании иностранного языка сотрудниками правоохранительных органов и потребность в повышении уровня подготовки в этой сфере (в основном общения на английском языке). Тот факт, что специализированные курсы английского языка по-прежнему являются важной частью учебных программ как национальных учебных заведений правоохранительных органов, так и двух крупнейших агентств $E$, занимающихся подготовкой сотрудников полиции, а также пограничной и береговой охраны (CEPOL и Frontex), показывает, что эта проблема в настоящее время все еще существует. В статье на основе качественного исследования дается обзор и оценка основных тенденций и инструментов электронного обучения, используемых в обучении английскому языку сотрудников правоохранительных органов в (ЕPOL u Frontex за последнее десятилетие, обсуждается прогресс, достигнутый в этой области как сточки зрения качества, так и методологии. В статье описываются технические ограничения некоторых инструментов электронного обучения и отмечается, что создатели курсов понимают, что виртуальное или реальноеприсутствие преподавателя является необходимым в процессе обучения на языковых курсах. 